\title{
Competitive Conditions in Nepalese Commercial Banks
}

\author{
Madhusudan Gautam*
}

DOI: https://doi.org/10.3126/jnbs.v14i1.41494

Received on 10 June 2021

Accepted on 28 October 2021

\begin{abstract}
This study aims to analyze the competitive conditions of commercial banks in Nepal. Competition is measured through structural and non-structural measures of bank competition. Data were taken from 21 commercial banks of Nepal using pooled sampling method, including five commercial banks based on the highest total assets and sixteen commercial banks using random sampling. Concentration ratio, Herfindahl-Hirschman Index, H-statistic and Lerner Index measures were used to assess the competitive position of Nepalese commercial banks. Panel data regression model with bank fixed effect and time fixed effect was employed to measure $H$-statistic and Lerner index. Findings showed the increasing pattern of capitalization and the decreasing trend of non-performing loan ratio, indicating that Nepalese commercial banks have a low possibility of loan default and, are more financially stable. It also showed the declining trend of bank concentration and HHI, suggesting that Nepalese commercial banks are losing their monopoly power and becoming more competitive in recent years. Competition in the loan market was found higher than deposit market competition. Banks have to pay special attention to loan portfolio management rather than deposit collection strategies. This study concludes that the competitive condition of Nepalese commercial banks is monopolistic. Therefore, appropriate strategies might be taken into action to sell financial products and services competitively.
\end{abstract}

Keywords: Bank concentration, competition, H-statistic, Lerner Index

\section{INTRODUCTION}

Competition in Nepalese banking has intensified especially after the encouragement of merger and acquisition, and the increase in paid-up capital policy (NRB, 2019). Competition in banking is important because it provides benefits to consumers by improving the choice of financial products and services, lowering borrowing interest rates and raising deposit interest rates (De-Ramon et al., 2018). To sustain in a competitive environment, banks are seeking new markets and providing diverse nature of financial services to increase profitability. Bank competition enhances economic growth with the improvement of financial efficiency in the banking market (Jayaratne \& Strahan, 1998). However, too much competition among banks could increase the solvency of particular banking institutions (Jimenez et al., 2013)as more competition leads to

\footnotetext{
* Mr. Gautam is an Assistant Professor at Shanker Dev Campus, Faculty of Management, Tribhuvan University, Nepal. Email: msgautamsdc@gmail.com

82
} 
lower borrowing interest rates which decline the revenue from performing loans of banks. It also hampers the financial stability of the entire banking system (Martinez-Miera \& Repullo, 2010).

In banking literature, there exist two types of bank competition measurements to evaluate banks' competitive behavior: structural measure and non-structural measure. The structural measure is based on the traditional measure of industrial organization. A structural approach to competition can be divided into structure conduct performance paradigm and efficiency structure hypothesis. The structure conduct performance (hereafter SCP) paradigm explains the behavior of firms and their performance. The SCP argues that greater bank market concentration lowers the competitive bank behavior which helps to increase the profitability of banks. Therefore, market structure drives the banks' conduct and ultimately increases the bank's performance. Thus, it is more focused on market structure rather than their conduct. In banking literature, the general structure is the number of banks, their capital structure and market structure of the banking industry. Capital structure implies the ownership position of banks whereas market structure shows firm-specific variables like the competition, regulations, etc., and macro-economic variables such as technological changes and economic situation of a particular country. In addition, conduct reveals the bank behavior and efficiency structure of banks. It incorporates the pricing, marketing, selling capacity of banks as well as efficiency to run the business. Likewise, performance implies the quantity and quality of various types of products and services offered by the banks. As per banking literature, market structure indicators such as bank concentration and ownership structure have a significant impact on the bank performance, but no significant influence on managerial decision making.

The SCP paradigm advocates that bank concentration can generate market power to produce profit potential from low-interest rate deposits and high-interest rate loans. This paradigm uses the market structure indicators such as market share of the largest banks in the banking industry or the Herfindahl-Hirschman Index (HHI) to assess the level of bank market concentration. Uhde and Heimshoff (2009) found market concentration has an inverse effect on profitability and capitalization. Shim (2019) added the direct relation between financial strength with bank competition. Findings suggested that a competitive market structure builds more confidence than a concentrated market structure. On the other hand, the efficiency structure hypothesis reported that the positive effect of bank concentration on profitability is not the result of market power, rather it is the effect of efficiency of banks having a larger market share. Thus, bank efficiency acts as the major force in the concentrated market.

In addition, previous empirical studies of Boyd et al. (2006); Angnir et al. (2014); Akins et al. (2016) and Goetz (2018) added that there is not always positive relation between market concentration and bank performance. Further, non-structural measures hows the degree of competition directly by addressing the bank's behavior. It requires the estimation of econometric equations based on theoretical models of price and banking output. The two major non-structural methods commonly accepted in bank market competition literature are Panzer and Rosse (1987) H-statistic and Lerner Index (1934) to examine the trend in competitive behavior over time.

Coccorese (2004) tested the degree of competition in the Italian context by taking both its main macro-region and the whole country for the period 1997-1999. Panzer and Rosse (1987) Hstatistic was used to assess bank competitive conditions. The results reported that Italian banks generate sufficient revenues if they are under monopolistic bank competition. Coccorese showed a positive relationship between economic performance at local level and competition among banks in Italy. In the Indian banking context, Prasad and Ghosh (2007) found evidence of monopolistic competition. Tabak et al. (2015) examined the competition behavior of the banking industry by employing H-statistic developed by Panzer and Rosse (1987). 
Tabak et al. employed unbalanced panel data of both commercial banks and conglomerates of Brazil for the period 2001-2011 and found that Brazilian banking industry was characterized as monopolistic. Capitalization was negatively related to bank risk-taking. At the bank level, the H-statistic had a negative influence on bank risk-taking in case of bank capital increase. Therefore, banks that experience an increase in market power are engaged in less risky banking activities rather than banks with decreasing market power. In the Nepalese context, Gajurel and Pradhan (2012) found the monopolistic bank market behavior for the period 2001 to 2009 in the Nepalese banking industry, rejecting the monopoly and perfect competition. However, there are remarkable changes in banks structure especially after the global financial crises of 2008/09. Neupane (2016) also found similar results consistent with Gajurel \& Pradhan (2012). Both studies lack to assess the bank competition from a market power perspective using Lerner index. Within this context, this study tries to examine bank market competitive conditions in Nepalese commercial banks from structural as well as non-structural approaches to make the results robust.

This paper has been organized into the following sub-sections: Section 2 provides the structure of Nepalese commercial banks. Section 3 shows the methodology adopted in this paper. Section 4 includes results and discussion with the analysis of different evaluation measures of bank competition and finally, section 5 includes the conclusion.

\section{STRUCTURE OF NEPALESE COMMERCIAL BANKS}

The banking industry in Nepal came into existence with the establishment of Nepal Bank Limited as first commercial bank in 1937 (NRB, 2019). Especially, Nepalese banking industry has expanded significantly, when it adopted the financial sector liberalization policy during 1980's. After the liberalization, many foreign banks entered into Nepalese market and private banks were established. As a result, the volume of commercial banks increased significantly. NRB (2019) reported that 68.3 percent share of total financial system comprised of commercial banks followed by development banks ( 8.7 percent), micro-finance companies (5.1 percent), finance companies ( 2.1 percent) respectively and the remaining was held by other contractual savings institutions and other institutions. Out of total of 27 commercial banks, there are 3 government banks, 7 joint venture banks and 17 private banks currently operating in the Nepalese banking industry.

The largest depository and lending institutions of Nepal are commercial banks which have a vital role in the economic development and expansion of financial services (Poudel et al., 2019). Major projects are financed through commercial bank loans. With the advancement of financial technology, people around the country are adopting various natures of cards, internet banking as well as mobile banking services for financial transactions. Thus, the access, scope and functions of commercial banks have become wider and broader (NRB, 2019).

Table 1 presents the major financial soundness indicators of Nepalese commercial banks such as the number of commercial banks, the number of bank branches, total assets, net profits, proportions of deposits and loans as a percentage of GDP, non-performing loan ratio, capitalization fund and capital to risk-weighted assets ratio from the fiscal year 2009/10 to $2018 / 19$. Initially, there were 27 banks in the fiscal year $2009 / 10$ and the numbers increased to 28 at the end of the fiscal year 2018/19. During the study period, there was a significant increase in banks up to 33 commercial banks once but the number gradually decreased due to encouragement of merger and acquisition policy and increase in paid-up capital policy adopted by Nepal Rastra Bank. Likewise, the number of bank branches also increased. There were 987 bank branches in 
the fiscal year 2009/10 which increased to 3,585 in the fiscal year 2018/19. An increase in the number of banks shows the improvement of the general public access to finance and supply of financial products and services. Further, a special campaign was proclaimed by Nepal Rastra Bank in the monetary policy of the fiscal year 2018/19 for opening a bank account to each local body. To encourage access to every local body, Nepal Rastra Bank allotted commercial banks to open bank branches to 735 local bodies (NRB, 2019).

\section{Table 1}

Financial Soundness Indicators of Commercial Banks

\begin{tabular}{lcccccccccc}
\hline Fiscal Year /Indicators & 2009 & 2010 & 2011 & 2012 & 2013 & 2014 & 2015 & 2016 & 2017 & 2018 \\
& $/ 10$ & $/ 11$ & $/ 12$ & $/ 13$ & $/ 14$ & $/ 15$ & $/ 16$ & $/ 17$ & $/ 18$ & $/ 19$ \\
\hline No of Banks & 27 & 31 & 32 & 31 & 30 & 30 & 28 & 28 & 28 & 28 \\
Bank Branches & 987 & 1245 & 1423 & 1486 & 1547 & 1672 & 1869 & 2274 & 3023 & 3585 \\
Total Assets & 787 & 878 & 1067 & 1267 & 1477 & 1774 & 2184 & 2621 & 3104 & 3687 \\
Net Profit & 16.04 & 15.6 & 15.88 & 21.06 & 23.14 & 27.66 & 38.13 & 45.43 & 53.63 & 65.22 \\
Deposit/GDP & 53.88 & 51.09 & 55.7 & 60.01 & 62.46 & 68.85 & 78.47 & 80.53 & 82.19 & 83.14 \\
Loan/GDP & 39.89 & 39.24 & 39.96 & 44.51 & 46.23 & 51.92 & 61.93 & 66.79 & 70.24 & 72.17 \\
NPL/Loan & 2.39 & 3.2 & 2.66 & 2.57 & 2.96 & 2.63 & 1.82 & 1.54 & 1.41 & 1.4 \\
Cap. Fund & 40.72 & 59.06 & 77.14 & 94.66 & 108.2 & 122.17 & 170.15 & 262.23 & 314.19 & 385.25 \\
Capital/RWA & 11.72 & 13.96 & 11.5 & 12.3 & 9.024 & 11.94 & 12.12 & 14.72 & 14.72 & 13.95
\end{tabular}

Source: Financial Stability Report (2019)

The size of total assets was Rs 787 billion in the fiscal year 2009/10 which increased to Rs 3,687 billion in the fiscal year 2018/19. Though restrictions to entry new banks have been placed, there has been a significant increase in the size of assets, due to an increase in the size of deposits and loans. The increase in the size of deposits is mainly determined by the rise of banking habits, increase in banking out rich supported by an increase in technology (NRB, 2019). The other reason to increase in assets might be the encouragement in merger and acquisition of banks, increase in paid-up capital, distributions of bonus shares and rights shares, and increase in retained earnings. The net profit was Rs16.04 billion in the fiscal year 2009/10 which increased to Rs 65.22 billion in the fiscal year 2018/19. It was almost four times more than the figure in the fiscal year 2009/10.

Similarly, Table 1 shows that there was a significant increase in the ratio of deposit to GDP and the ratio of loan to GDP over the period. An increase in both deposits to GDP and loan to GDP showed their relative importance in the Nepalese economy. The ratio of non-performing loan to total loan was in decreasing trend, suggesting that Nepalese commercial banks can reduce non-performing loan and improve the quality of the assets of banks. It also provides evidence of banking stability. The capitalization fund increased from 40.72 billion in the fiscal year 2009/10 to 385.25 billion in the fiscal year 2018/19. The ratio of capital to total risk-weighted assets was also increased from 11.72 percent in the fiscal year 2009/10 to 13.95 percent in the fiscal year 2018/19, showing the increasing trend. The reason behind this is mainly two. First, Nepal Rastra bank encouraged the banks and finance companies for mergers and acquisitions by offering various incentives. Second, it increased the paid-up capital of banks because higher capital ratios indicate the safer and stable from a regulatory perspective. 
Overall, the financial indicators are in an increasing pattern from the fiscal year 2009/10 to the fiscal year 2018/19. The increasing patterns of capitalization ratios are evidence of safety and stability in the Nepalese banking system. The decreasing trend of non-performing loan ratio shows that Nepalese commercial banks have a lower probability of loan default and they are more financially stable.

\section{METHODOLOGY}

The unit of analysis for this study is the commercial banks of Nepal. This study follows positivist philosophy and a quantitative approach to assess the competition in Nepalese commercial banks. Commercial banks occupy more than two-third portion of market share of the total banking system and have a dominant role in banking development (NRB, 2019). Descriptive and causal research designs have been employed to find bank competitiveness in Nepalese commercial banks. Bank competition is a key variable of interest and is measured through both structural and non-structural approaches. The structural approach is based on the structure conduct paradigm whereas the non-structure approach emphasizes the analysis of competitive conduct rather than the structure of the bank market. This study incorporates both approaches to make the results robust.

\subsection{Structural Measures of Bank Competition}

Concentration ratio and Herfindahl-Hirschman Index are two key measures of bank concentration (Beck et al., 2006; Jimenez et al., 2013; Shim, 2019). Concentration ratio is used to measure the level of concentration held by top ' $n$ ' largest banks. It is extensively used measures due to its simplicity in nature and limited data requirements. It is the sum of market shares of ' $n$ ' largest banks in banking industry which can be computed by using following relation:

$$
\mathrm{CR}_{\mathrm{n}}=\sum_{\mathrm{i}=1}^{\mathrm{n}} \mathrm{S}_{\mathrm{i}}
$$

Where $S_{i}$ refers to the market share of each bank ' $i$ ' and $n$ indicates the number of largest banks. The choice of ' $n$ ' is to some extent subjective but usually 3 and 5. Concentration ratios allocate the same weight to each bank and do not reflect the effect of small size banks. The concentration ratio varies from 0 to 1 . It becomes zero when there is infinite numbers of banks of equal size and approaches 1 if banks considered generating the entire banking industry (Bikker \& Haaf, 2002).

Another popular structural measure of bank competition is Herfindahl-Hirschman Index (HHI). HHI is the sum of squares of market share of each bank in the industry and computed as:

$$
\mathrm{HHI}=\Sigma_{\mathrm{i}=1}^{\mathrm{k}} \mathrm{s}_{\mathrm{i}}^{2}
$$

Where $\left(\mathrm{S}_{\mathrm{i}}\right)^{2}$ is the square of market share of $\mathrm{i}^{\text {th }}$ bank. The value of HHI ranges from 0 to 10000 (Bikker \& Haff, 2002). The value of HHI equal to zero indicates perfect competition whereas 10000 shows a monopoly market. It is also regarded as a full information index as it includes for all sizes of banks. This study uses three banks and five banks concentration based on the assets, deposit and loans as well as HHI based on assets, deposits and loans to observe the bank market concentration from the perspective of deposit market, loan market and overall market. 


\subsection{Non-Structural Measures of Bank Competition}

Panzer and Rosse (1987) H-statistic and Lerner Index (1934) are two major nonstructural measures to estimate the trend in competitive behavior over time. H-statistic uses firmlevel data. It shows the degree to which a change in factor input prices is shown in revenue earned by the bank. The reason behind this is that banks in equilibrium choose prices and quantities in a way that marginal revenue equals marginal cost. However, it may vary with depending on the market competitiveness. For example, in perfect competition, an increase in factor input prices increases marginal cost and total revenues equally as cost increases. In monopolistic competition, the increase in factor input prices reduces outputs and total revenues but increases marginal costs. The H-statistic shows the numerical measure of the degree of bank market competition. When the $\mathrm{H}$-statistic is zero, it implies a monopoly market. When the $\mathrm{H}$-statistic is one, it suggests the perfect competition. The intermediate value provides monopolistic competition in nature. This study uses the same methodology used by Bikker \& Haaf (2002), and Claessens \& Laeven (2004) to compute $\mathrm{H}$-statistic. The reduced form of revenue equation is:

$$
\ln (\mathrm{P})=\alpha+\beta_{1} \cdot \ln \left(\mathrm{W}_{1}\right)+\beta_{2} \cdot \ln \left(\mathrm{W}_{2}\right)+\beta_{3} \cdot \ln \left(\mathrm{W}_{3}\right)+\gamma_{1} \cdot \ln \left(\mathrm{Y}_{1}\right)+\gamma_{2} \cdot \ln \left(\mathrm{Y}_{2}\right)+\gamma_{3} \cdot \ln \left(\mathrm{Y}_{3}\right)+\delta \cdot \mathrm{D}+\varepsilon(3)
$$

Where, $\mathrm{P}$ denotes the ratio of total revenue to total assets, $\mathrm{W}_{1}, \mathrm{~W}_{2}$, and $\mathrm{W}_{3}$ represent the ratio of interest expenses to total deposits (input price of deposits), ratio of personnel expense to total assets (input price of labor), and the ratio of other operating and administrative expense to total assets (input price of fixed capital) respectively. $\mathrm{Y}_{1}, \mathrm{Y}_{2}$ and $\mathrm{Y}_{3}$ indicate the ratio of equity to total assets, ratio of net loans to total assets and log of total assets to capture size effects respectively. $\mathrm{D}$ and $\varepsilon$ are dummy variables and error term respectively. The H-statistic is the sum of elasticity of input prices i.e. $\beta_{1}+\beta_{2}+\beta_{3}$ (Bikker \& Haaf, 2002).

Lerner Index is another non-structural measure of competition. It provides the capacity of market power showing the difference between price and marginal cost as a percentage of the price. Therefore, it is the mark-up price over marginal costs. (Berger et al., 2009). Like H-statistic, the value of Lerner Index also ranges from 0 to 1 . Lerner Index is 1 in the monopoly market and 0 in perfect competition. A value less than 0 indicates the pricing below marginal costs and shows the non-optimal bank behavior. The Lerner Index in between 0 and 1 reveals the monopolistic competition. This study follows the methodology used in Turk Ariss (2010), Beck et al. (2013), and Anginer et al. (2014) to compute marginal cost using trans log cost function and Lerner Index. It can be calculated as follows:

Lerner Index $(\mathrm{LI})=\frac{\mathrm{P}-\mathrm{MC}}{\mathrm{P}}$

The marginal cost is not directly observable. The marginal cost is derived empirically from the parameters of an estimated total cost function which is as follows:

$$
\begin{aligned}
\log \left(\mathrm{C}_{\mathrm{it}}\right)= & \alpha+\beta_{1} \cdot \log \left(\mathrm{Q}_{\mathrm{it}}\right)+\beta_{2} \cdot \log \left(\mathrm{Q}_{\mathrm{it}}\right)^{2}+\beta_{3} \cdot \log \left(\mathrm{W}_{1 . \mathrm{it}}\right)+\beta_{4 \cdot} \log \left(\mathrm{W}_{2 . \mathrm{it}}\right)+\beta_{5 .} \log (3 . \mathrm{it})+\beta_{6 .} . \\
& \log \left(\mathrm{Q}_{\mathrm{it}}\right) \cdot \log \left(\mathrm{W}_{1 . \mathrm{it}}\right)+\beta_{7} \cdot \log \left(\mathrm{Q}_{\mathrm{it}}\right) \cdot \log \left(\mathrm{W}_{2 . \mathrm{it}}\right)+\beta_{8} \cdot \log \left(\mathrm{Q}_{\mathrm{it}}\right) \cdot \log \left(\mathrm{W}_{3 . \mathrm{it}}\right)+\beta_{9 .} . \\
& \log \left(\mathrm{W}_{1 . \mathrm{it}}\right)^{2}+\beta_{10 .} \log \left(\mathrm{W}_{2 . \mathrm{it}}\right)^{2}+\beta_{11} \cdot \log \left(\mathrm{W}_{3 . \mathrm{it}}\right)^{2}+\beta_{12 .} \log \left(\mathrm{W}_{1 . \mathrm{it}}\right) \cdot \log \left(\mathrm{W}_{2 . \mathrm{it}}\right)+\beta_{13 .} . \\
& \log \left(\mathrm{W}_{1 . \mathrm{it}}\right) \cdot \log \left(\mathrm{W}_{3 . \mathrm{it}}\right)+\beta_{14 .} \log \left(\mathrm{W}_{2 . \mathrm{it}}\right) \cdot \log \left(\mathrm{W}_{3 . \mathrm{it}}\right)+\varepsilon_{\mathrm{it}}
\end{aligned}
$$

Where MC refers to the marginal cost of total assets for the bank. $\mathrm{C}$ indicates total cost which is equal to the sum of interest expenses, commission and fee expenses, trading expenses, personnel expenses, other administrative expenses and operating expenses measured in rupees. Q is the quantity of output and is measured as total assets in billions of rupees. The marginal cost $(\mathrm{MC})$ can be calculated by using the following relations:

$\mathrm{MC}=\delta \mathrm{C} / \delta \mathrm{C}=\mathrm{C}_{\mathrm{it}} / \mathrm{Q}_{\mathrm{it}}\left[\beta_{1}+2 \cdot \beta_{2} \cdot \log \left(\mathrm{Q}_{\mathrm{it}}\right)+\beta_{6} \cdot \log \left(\mathrm{W}_{1}\right)+\beta_{7} \cdot \log \left(\mathrm{W}_{2}\right)+\beta_{8} \cdot \log \left(\mathrm{W}_{3}\right)\right.$

This study has used various data sources such as the Nepal Rasta Bank (NRB) database, 
Nepal stock exchange (NEPSE) database, Security Board of Nepal (SEBON) database and respective sample banks' annual reports to collect the required information for analysis. All commercial banks licensed by the Nepal Rastra Bank (NRB) till mid-July 2019 are considered as the population for the study. It includes only those commercial banks which are involved in commercial trading and required financial information is available for the study period. This study has used 21 commercial banks of Nepal as sample banks over the period 2009/10 to 2018/19 as many structural and regulatory changes in terms of increase in bank paid-up capital, adoption of Basel II and III, restrictions to open new banks, encouragement of merger etc. have been made especially after the global financial crisis. While selecting the sample, this study has used the pooled sampling method following Beck et al. (2013) and selected the top five banks in assets to observe the level of concentration plus random sampling method for remaining to examine the bank competitiveness. This study has adopted a panel data regression model with bank fixed effect and time fixed effect to examine the competitive condition. To apply this model, several other tests such as Chow test, Hausman test, Langrang test are applied. Wald test has been performed to check whether the time fixed effect is necessary or not. Woolridge test has been performed to find whether there is a presence of serial correlation or not.

\section{RESULTS AND DISCUSSION}

This study uses the five banks and three banks concentration ratios based on loans, deposits and total assets to examine the level of market concentration in commercial banks of Nepal over the period 2009/10-2018/19. The higher value of concentration ratio represents the lower competitive behavior and vice-versa.

Table 2 depicts that five banks' concentration on assets, deposits and loans were 0.3992., 0.3880., and 0.3801 respectively in the fiscal year 2009/10 which showed the almost same status of market concentration. The five banks' concentration ratio in the fiscal year 2010/11 were 0.3867 in assets, 0.3825 in deposits and 0.3620 in loans. However, these ratios gradually decreased to 0.2868 in assets, 0.2823 in deposits and 0.2711 in loans respectively, showing a declining trend.

Table 2 also indicates that the three banks' concentration ratios were 0.2662 in assets, 0.2616 in deposits, and 0.2477 in loans in the fiscal year 2009/10. In the fiscal year 2018/19, the three bank assets concentration, deposits concentration and loans concentration declined significantly and showed the competitive position of Nepalese commercial banks. Further, both concentration ratios indicated that mean loan concentration is lower than mean deposits and mean assets concentration, implying competition is higher in the loan market than deposit market.

The five banks and three banks' concentration ratios demonstrate the level of market concentration held by top banks. If these top banks fail, the whole financial situation of the banking industry may deteriorate. Therefore, the failure of large banks has a huge impact on financial stability. However, the n-bank concentration ratio does not account for each bank concentration level in the banking industry. To overcome the shortcoming of n-bank concentration, another popular structural measure of bank competition called HHI is taken into account. HHI is the squares of each bank's market share.

Table 3 presents the structure of HHI based on loans, deposits and assets from the fiscal year 2009/10 to 2018/19. Initially, HHI on assets, deposits and loans were 720.88., 708.31 and 674.65 respectively in the fiscal year 2009/10. These HHIs were declined to 521.43., 513.20 and 516.89 respectively in the fiscal year 2018/19. The decline in HHIs on assets, loans and deposits showed evidence that market concentration in Nepalese commercial banks is declining and banking market is becoming more competitive. 


\section{Table 2}

Structure of Five and Three Banks Concentration Ratios Based on Assets, Deposits and Loans

\begin{tabular}{lcccccc}
\hline & \multicolumn{3}{c}{ Five banks concentration } & \multicolumn{3}{c}{ Three banks concentration } \\
\cline { 2 - 7 } Fiscal Year & CR5 Assets & CR5 Deposits & CR5 Loans & CR3 Assets & CR3 Deposits & CR3 Loans \\
\hline $2009 / 10$ & 0.3992 & 0.3880 & 0.3801 & 0.2662 & 0.2616 & 0.2477 \\
$2010 / 11$ & 0.3867 & 0.3825 & 0.3620 & 0.2535 & 0.2527 & 0.2311 \\
$2011 / 12$ & 0.3647 & 0.3562 & 0.3351 & 0.2420 & 0.2314 & 0.2133 \\
$2012 / 13$ & 0.3483 & 0.3361 & 0.3185 & 0.2258 & 0.2133 & 0.2023 \\
$2013 / 14$ & 0.3434 & 0.3252 & 0.3102 & 0.2248 & 0.2129 & 0.2008 \\
$2014 / 15$ & 0.3361 & 0.3240 & 0.3083 & 0.2226 & 0.2181 & 0.1977 \\
$2015 / 16$ & 0.3228 & 0.3071 & 0.2897 & 0.2109 & 0.2069 & 0.1851 \\
$2016 / 17$ & 0.2976 & 0.2866 & 0.2761 & 0.1946 & 0.1902 & 0.1767 \\
$2017 / 18$ & 0.2885 & 0.2845 & 0.2728 & 0.1834 & 0.1864 & 0.1721 \\
$2018 / 19$ & 0.2868 & 0.2823 & 0.2711 & 0.1823 & 0.1847 & 0.1705 \\
\hline Mean & 0.3374 & 0.3273 & 0.3124 & 0.2206 & 0.2158 & 0.1997 \\
\hline St. Dev. & 0.0393 & 0.0388 & 0.0376 & 0.0285 & 0.0264 & 0.0255 \\
\hline
\end{tabular}

Note. This table represents the five banks and three banks' concentration ratios based on assets, deposits and loans. Three banks concentration is the sum of market share of the three largest commercial banks and five banks concentration is the sum of the market share of the five largest commercial banks in Nepal over the period 2009/10 to 2018/19. Data were collected from NRB database and respective banks' annual reports. The mean value indicates the average of three banks and five banks' concentration. Standard deviation is the variability in concentration ratio over the period.

Table 3 further reveals the mean values of HHI on assets, deposits and loans and their respective standard deviations. The mean value of HHI on assets were 604.39 with standard deviation of 71.12. The mean value of HHI on deposits was 597.79 with standard deviation of 70.42 and the mean value of HHI on loans was 572.89 with standard deviation of 55.36. These imply that the competition on loan was more competitive among Nepalese commercial banks than competition on deposits and assets, consistent with the results of three banks and five banks concentration in Table 2.

To strengthen the financial status and trustworthiness of commercial banks, NRB has continuously prioritized mergers between finance companies, development banks and commercial banks by providing many regulatory relaxations, incentives and consolidations. NRB has also projected to generate the benefits of becoming a large financial institution, strengthen its capacity to produce and distribute financial products and services through the use of financial technology at lower cost and build resilience to various micro as well as macro-economic shocks. On contrary to the NRB priority, three banks and five banks concentration ratios and HHI on deposits, loans and assets showed that market concentration in commercial banks are decreasing, implying an increase in market competition. Further, competition in loans is found to be more competitive than assets competition and deposits competition, indicating that Nepalese commercial banks are continuously providing their financial services, especially loans on more competitive basis. 


\section{Table 3}

Structure of HHI Based on Assets, Loans and Deposits

\begin{tabular}{|c|c|c|c|}
\hline Fiscal Year & HHI Assets & HHI Deposits & HHI Loans \\
\hline $2009 / 10$ & 720.88 & 708.31 & 674.65 \\
\hline $2010 / 11$ & 701.10 & 703.62 & 646.55 \\
\hline $2011 / 12$ & 661.55 & 652.81 & 607.61 \\
\hline $2012 / 13$ & 613.66 & 603.95 & 577.93 \\
\hline $2013 / 14$ & 608.47 & 598.11 & 573.97 \\
\hline $2014 / 15$ & 589.02 & 580.80 & 558.67 \\
\hline $2015 / 16$ & 562.02 & 553.93 & 532.40 \\
\hline $2016 / 17$ & 539.45 & 534.79 & 523.64 \\
\hline $2017 / 18$ & 526.33 & 528.43 & 517.23 \\
\hline $2018 / 19$ & 521.43 & 513.20 & 516.24 \\
\hline Mean & 604.39 & 597.79 & 572.89 \\
\hline St. Dev. & 71.12 & 70.42 & 55.36 \\
\hline
\end{tabular}

Note. This table presents the HHI based on assets, deposits and loans. HHI is the sum of the square of market share of each bank operated in Nepalese commercial banks over the period 2009/10 to 2018/19. Data were collected through the NRB database and respective banks' annual reports. The mean is the average value of the respective $\mathrm{HHI}$ and the standard deviation is the variability in HHI over the period.

A non-structural measure of bank competition measures the degree of competition directly by addressing the bank's behavior. Two major non-structural methods widely employed in bank market competition are Panzer and Rosse (1987) H-statistic and Lerner Index. Panzer and Rosse (1987) H-statistic uses the bank-level data and finds a change in factor input prices reflected in revenue earned by a particular bank. Table 4 provides the descriptive statistics of the variables used for working out of Panzer and Rosse (1987) H-statistic.

\section{Table 4}

Descriptive Statistics of Panzer and Rosse (1987) H-Statistic Variables

\begin{tabular}{lcccl}
\hline Variables & Mean & St. Dev. Min. & Max. \\
\hline Log of Total Revenue (logtr) & 8.53 & 0.69 & 6.37 & 10.00 \\
Log of Interest Expenses to Total Assets Ratio(logw1) & 1.34 & 0.44 & 0.02 & 2.10 \\
Log of staff expenses to Total Asset Ratio (logw2) & 0.44 & 0.31 & 0.01 & 1.77 \\
Log of Administrative and Operating Expenses to Total Assets & 0.58 & 0.17 & 0.01 & 1.29 \\
Ratio(logw3) & & & & \\
Log of Equity to Assets Ratio(logy1) & 2.91 & 0.39 & 0.03 & 3.51 \\
Log of Loan to Total Assets Ratio(logy2) & 4.13 & 0.15 & 3.63 & 4.33 \\
Log of Total Assets (logy3) & 10.97 & 0.72 & 8.91 & 12.47 \\
\hline
\end{tabular}

Note. This table reports summary statistics on the variables used in the estimations of Panzer and Ross (1987) H-statistic. The sample includes 21 commercial banks in Nepal with total of 207 observations. Data were collected from the NRB database and respective banks' annual reports for the period $2009 / 10$ to $2018 / / 19$.

The results indicated that an average bank in the sample had log total revenue of $8.53, \log$ interest expenses to total asset ratio of $1.34, \log$ staff expenses to total assets ratio of $0.44, \log$ administrative and operating expenses to total assets ratio of $0.58, \log$ equity to assets ratio of 
$2.91, \log \operatorname{loans}$ to total assets ratio of 4.13 and finally $\log$ total assets of 10.97 . The log of total revenue ranged from a minimum of 6.37 to a maximum of 10 with a standard deviation of 0.69 . The $\log$ interest expenses to total assets were minimum of 0.02 and a maximum of 2.10 with a standard deviation of 0.44. Similarly, the log value of staff expenses ratio ranged from 0.01 to 1.77 and with a standard deviation of 0.31 . The minimum log value of administrative and operating expenses ratio, equity to asset ratio, loan to total assets and total assets were $0.01 ; 0.03 ; 3.63$ and 8.91 respectively whereas their maximum value were $1.77 ; 1.29 ; 3.51 ; 4.33$ and standard deviation of $0.17 ; 0.39 ; 0.15$ and 0.72 respectively.

Table 5 provides the Pearson correlation coefficient between variables used for estimation of Panzer and Rosse (1987) H-statistic. The results indicated that there was a negative and significant relation between log value of total revenue and $\log$ value of interest expenses to total assets $(r=-0.2368)$, and $\log$ value of total revenue and $\log$ value of administrative and operating expenses to total assets $(r=-0.3679)$. It implies that banks should properly minimize the various administrative and other operating expenses and manage deposit portfolios with a minimum interest rate to increase the total revenue.

\section{Table 5}

Relationship among Panzer and Rosse (1987) H-Statistic Variables

\begin{tabular}{lccccccc}
\hline Variables & Logtr & Logw1 & Logw2 & Logw3 & Logy1 & Logy2 & Logy3 \\
\hline Logtr & 1 & & & & & & \\
Logw1 & -0.2368 & 1 & & & & \\
& $(0.0006)$ & & & & & \\
Logw2 & 0.3308 & -0.3346 & 1 & & & \\
& $(0.0000)$ & $(0.0000)$ & & & & \\
Logw3 & -0.3679 & 0.3622 & -0.1996 & 1 & & \\
& $(0.0000)$ & $0.0000)$ & $(0.0000)$ & & & \\
Logy1 & -0.0179 & 0.2829 & -0.3573 & 0.1366 & 1 & \\
& $(0.7974)$ & $(0.0000)$ & $(0.0000)$ & $(0.0497)$ & & \\
Logy2 & 0.0286 & 0.5889 & -0.3464 & 0.2353 & 0.4680 & 1 \\
& 0.6824 & $(0.0000)$ & $(0.0000)$ & $(0.0006)$ & $(0.0006)$ & & \\
Logy3 & 0.9578 & -0.4236 & 0.2750 & -0.4430 & -0.0839 & -0.0798 & 1 \\
& $(0.0000)$ & $(0.0000)$ & 0.0001 & $(0.0000)$ & $(0.2296)$ & $(0.2529)$ & \\
\hline
\end{tabular}

Note. This table reports the correlation coefficient between variables used for computation of Panzer and Rosse (1987) H-statistic. The sample includes 21 commercial banks in Nepal with a total of 207 observations. Data were collected from the NRB database and respective banks' annual reports for the period $2009 / 10$ to $2018 / / 19$. The logtr denotes the $\log$ of total revenue, logw1 indicates $\log$ value of interest expenses to total assets. The logw 2 and $\log w 3$ denote $\log$ value of staff expenses to total assets and $\log$ value of administrative and operating expenses to total assets respectively. Similarly, logy1, $\log 2$ and $\log 3$ indicate the $\log$ value of equity to total assets, loans to total assets and total assets respectively.

The positive and significant relation between log value of total revenue and the log value of staff expenses to total assets $(r=0.3308)$ showed the human resource efficiency to generate revenue. Similarly, there was a significant and highly positive relation between log value of total revenue and $\log$ value of total assets $(r=0.9578)$, indicating that high-size firms can generate more revenue. The correlation coefficient between all independent variables had significant relationship except log value of equity to assets and log value of total assets. Further, there is not 
high correlation between explanatory variables which provides the evidence that regressors are free from multi-collinearity problems.

Table 6 shows regression results for the estimation of Panzer and Rosse (1987) Hstatistic. The dependent variable is log value of total revenue. The major explanatory variables for computation of H-statistic are log value of interest expenses to total assets, log value of staff expenses to total assets, log value of administrative and operating expenses to total assets and control variables include log of equity to total asset, log of administrative and operating expenses to total assets and log value of total assets respectively. H-statistic provides the degree to which a change in factor input prices is reflected in bank revenue. The value of H-statistic with zero or less indicates monopoly and the value of $\mathrm{H}$-statistic in between zero and one shows monopolistic competition and the value of $\mathrm{H}$-statistic of one is the condition of perfect competition.

\section{Table 6}

Regression Coefficients of Panzer and Rosse (1987) H-Statistic

\begin{tabular}{lcccc}
\hline Variables & Coefficients & Std. Error & t-value & p-value \\
\hline logw1 & 0.3138 & 0.0234 & 15.9795 & 0.0000 \\
logw2 & 0.3814 & 0.0595 & 6.7476 & 0.0000 \\
logw3 & 0.2059 & 0.0528 & 3.8985 & 0.0001 \\
logy1 & 0.0305 & 0.0254 & 1.2047 & 0.2299 \\
logy2 & 0.3315 & 0.0932 & 3.5560 & 0.0005 \\
logy3 & 0.9734 & 0.0136 & 71.7467 & 0.0000 \\
Bank Fixed Effects & Yes & & & \\
\hline Adjusted R ${ }^{2}$ & F Statistic & p-value of F & p-value of & H Statistic \\
$=0.8922$ & $=1236.27$ & Statistic $=0.0000$ & Woolridge test $=$ & $=0.9011$ \\
& & & 0.0000 & $\mathrm{~N}=207$
\end{tabular}

Note. This table reports the regression results of variables used for computation of Panzer and Rosse (1987) H-statistic using fixed effects panel data model with bank fixed effect. The sample includes 21 commercial banks in Nepal with total 207 observations. Data were collected from the NRB data base and respective banks' annual reports for the period 2009/10 to 2018//19. The logw1 indicates log value of interest expenses to total assets. The $\log w 2$ and $\log w 3$ denote $\log$ value of staff expenses to total assets and $\log$ value of administrative and operating expenses to total assets respectively. Similarly, $\log 1, \log 22$ and $\log 33$ indicate the $\log$ value of equity to total assets, loans to total assets and $\log$ of total assets respectively.

Table 6 indicates that $\log$ value of interest expenses to total assets, log value of staff expenses to total assets and log value of administrative and operating expenses to total assets were positive and significant at 1 percent level. The other controls like log value of loans to total assets, $\log$ value of total assets were also positive and significant at 1 percent level but log value of equity to total assets had a positive but insignificant relationship with log value of total revenue. While considering the log value of total revenue as the dependent variable, the model was significant at 1 percent level $(F=1236.27$ and $p=0.0000)$. The adjusted $\mathrm{R}$ square was 89.22 percent which shows the variation explained by explanatory variables on log of total revenue. Since the $H$-statistic is computed with a sum of factor input prices (i.e. $H=\beta_{1}+\beta_{2}+\beta_{3}$ ), then the value of $\mathrm{H}$-statistic becomes 0.9011 . Thus, the $\mathrm{H}$-statistic value suggests that the competition among Nepalese commercial banks is monopolistic.

Another non-structural measure of bank market competition is Lerner Index. Lerner Index provides the market power of price by calculating the difference between price and 
marginal cost as a percentage over price (Berger et al., 2009; Turk Ariss, 2010). Table 7 presents the Lerner Index from sample banks for the period 2009/10 to 2018/19, capturing the details of the coefficient of input variables for the computation of marginal cost, their ' $t$ ' value and level of significance from the trans $\log$ cost function and Lerner Index.

Table 7 indicates that all regression coefficients were statistically significant at 1 percent level except log of total assets which was significant at 5 percent level. The overall model was also significant at 1 percent level $(\mathrm{F}=4402.1, \mathrm{p}=0.0000)$. The adjusted $\mathrm{R}$ square was 0.95 which suggested that explanatory variables have 95 percent explanatory power on the variation of the dependent variable. The marginal cost computed was 5.4907. The price is regarded as log of total revenue which was 8.5296. The major concern is Lerner Index which was 0.3563 . The Lerner Index of less than one (i.e. $0.3563<1$ ) implies monopolistic competition. Thus, the competition among Nepalese commercial banks is considered monopolistic competition.

\section{Table 7}

Regression Coefficients and Value of Lerner Index

\begin{tabular}{|c|c|c|c|c|}
\hline Variables & Coeff. & Std. Error & t-value & p-value \\
\hline $\log q 1\left(\beta_{1}\right)$ & 1.0404 & 0.0214 & 48.7250 & 0.0000 \\
\hline $\log q 1$ squared & -0.0019 & 0.0009 & -2.0642 & 0.0410 \\
\hline $\log w 1$ & 0.6153 & 0.0273 & 22.5704 & 0.0000 \\
\hline $\log w 2$ & 0.6236 & 0.0478 & 13.0537 & 0.0000 \\
\hline $\log w 3$ & 0.7866 & 0.0680 & 11.5594 & 0.0000 \\
\hline $\log q 1 \log w 1\left(\beta_{6}\right)$ & 0.0060 & 0.0021 & 2.7933 & 0.0050 \\
\hline $\log _{q} 1 \log _{w} 2\left(\beta_{7}\right)$ & -0.0007 & 0.0040 & -0.1820 & 0.0000 \\
\hline $\log _{q} 1 \log _{w} 3\left(\beta_{8}\right)$ & -0.0159 & 0.0051 & -3.1074 & 0.0000 \\
\hline logw1squared & 0.1039 & 0.0021 & 49.2010 & 0.0000 \\
\hline $\log 2$ squared & 0.1124 & 0.0042 & 26.8360 & 0.0000 \\
\hline logw3squared & 0.0873 & 0.0108 & 8.0571 & 0.0000 \\
\hline $\log _{w} 1 \log _{w} 2$ & -0.2593 & 0.0044 & -59.4373 & 0.0000 \\
\hline $\log _{w} 1 \log _{w} 3$ & -0.2335 & 0.0085 & -27.5006 & 0.0000 \\
\hline $\log _{w} 2 \log _{w} 3$ & -0.1111 & 0.0109 & -10.2010 & 0.0000 \\
\hline Bank fixed effects & Yes & & & \\
\hline Time fixed effects & Yes & & & \\
\hline
\end{tabular}

Adjusted $\mathrm{R}^{2}=0.95 \mathrm{~F}$-statistic $=402.1 \mathrm{p}$-value of Woolridge test $=0.0000$

p-value of F Statistic $=0.000$

$\mathrm{N}=207$

$\mathrm{MC}_{\mathrm{it}}=\mathrm{C}_{\mathrm{it}} / \mathrm{Q}_{\mathrm{it}}\left[\beta_{1}+2 \cdot \beta_{2} \cdot \log \left(\mathrm{Q}_{\mathrm{it}}\right)+\beta_{6} \cdot \log \left(\mathrm{W}_{1}\right)+\beta_{7} \cdot \log \left(\mathrm{W}_{2}\right)+\beta_{8} \cdot \log \left(\mathrm{W}_{3}\right)=5.4907\right.$

Lerner Index $=\left(\mathrm{P}_{\mathrm{it}}-\mathrm{MC}_{\mathrm{it}}\right) / \mathrm{P}_{\mathrm{i}}=0.356$

Note. This table reports the regression coefficient of variables used for computation of Lerner Index using a fixed-effects regression model with bank fixed effect and time fixed effect. The sample includes 21 commercial banks in Nepal with total of 207 observations. Data were collected from the NRB database and respective banks' annual reports for the period 2009/10 to 2018//19. The logw1 indicates $\log$ value of interest expenses to total assets. The $\log w 2$ and $\log w 3$ denote $\log$ value of staff expenses to total assets and $\log$ value of administrative and operating expenses to total assets respectively. Similarly, $\log 1, \log 2$ and $\log 3$ indicate the $\log$ value of equity to total asset, administrative and operating expenses to total assets and total assets respectively. 


\section{CONCLUSION}

This study investigates the competitive condition in Nepalese commercial banks using 21 commercial banks over the period 2009/10 to 2018/19. The competitive conditions are measured through the different proxies of bank concentration and competition. This study has a significant contribution to banking literature. It has also policy implications. The decreasing level of market concentration implies that Nepalese commercial banks are losing their market power and becoming more competitive. Concerning regulatory authorities have to pay special attention while formulating competition policy, regulation and supervision policy. This study concludes that Nepalese commercial banks are characterized by monopolistic competition. Therefore, banks might offer financial products and services adopting a differentiation strategy to compete more among commercial banks.

\section{REFERENCES}

Akins, B., Li, L., Ng, J., \& Rusticus, T. (2016). Bank competition and financial stability: Evidence from the financial crisis. Journal of Financial and Quantitative Analysis, 51(1), 1-28.

Anginer, D., Demirguc-Kunt, A., \& Zhu, M. (2014). How does competition affect bank systemic risk? Journal of Financial Intermediation, 23 (1), 1-26.

Bain, J. S. (1951). Relation of Profit rate to industry concentration. Quarterly Journal of Economics, 65, 293-324.

Beck, T., De Jongle, O., \& Schepens, G. (2013). Bank competition and stability: Cross-country heterogeneity. Journal of Financial Intermediation, 22, 218-244.

Beck, T., Demirguc-Kunt, A., \& Levine, R. (2006). Bank concentration, competition and crisis: First results. Journal of Banking \& Finance, 30 (5), 1581-1603.

Berger, A.N., Klapper, L. F., \& Turk Ariss, R. (2009). Bank competition and financial stability. Journal of Financial Service Research, 35, 99-118.

Bikker, J.A., \& Haff, K. (2002). Competition, concentration and their relationship: An empirical analysis of banking industry. Journal of Banking \& Finance, 26, 2191-2214.

Boyd, J., De Nicolo, G., \& Jalal, A.M. (2006). Bank risk taking and competition revisited: New theory and evidence (IMF Working Paper No. 297). International Monetary Fund.

Claessens, S., \& Laeven, L. (2004). What drives bank competition? Some international evidence. Journal of Money, Credit and Banking, 36 (3), 563-583.

Coccorese, P. (2004). Banking competition and macro-economic conditions: A disaggregated analysis. Journal of International Financial Markets, Institutions and Money, 14, 203-219.

De-Raman, S., Francis, W.B., \& Straughan, B. (2018). Bank competition and stability in United Kingdom (Working Paper No.748). Bank of England.

Gajurel, D. P., \& Pradhan, R. S. (2012). Competition and concentration on Nepalese banking. Journal of Business, Economics and Finance, 1(1), 5-16.

Goetz, M. R. (2018). Competition and financial stability. Journal of Financial Intermediation, 35(a), 57-69.

Jayaratne, J., \& Strahan, P. (1998). Entry restrictions, industry evolution and dynamic efficiency: Evidence from commercial banking. The Journal of Law and Economics, 41(1), 239274.

Jimenez, G., J. A. Lopez., \& Saurina, J. (2013). How does competition affect bank risk-taking? Journal of Financial Stability, 9, 185-195.

Lerner, A. P. (1934). The concept of monopoly and the measurement of monopoly power. The 
Review of Economic Studies, 1 (3), 157-175.

Leroy, A., \& Lucotte, Y. (2017). Is there a competition-stability trade-off in European banking? Journal of International Financial Markets, Institutions and Money, 46, 199-215.

Martinez- Miera, D., \& Repullo, R. (2010). Does competition reduce the risk of bank failure? The Review of Financial Studies, 23 (10), 3638-3664.

Nepal Rastra Bank. (2010-2015). Banking and Financial Statistics. Banks and Financial Institution Regulation Department. NRB.

Nepal Rastra Bank. (2016-2019). Monthly Statistics. Banks and Financial Institution Regulation Department. NRB.

Nepal Rastra Bank. (2019). Financial Stability Report. NRB.

Neupane, B.P. (2016). Competition on Nepalese commercial banks. NRB Economic Review, 28(2), 75 89.

Panzer, J. C., \& Rosse, J. N. (1987). Testing for monopoly equilibrium. The Journal of Industrial Economics, 35 (4), 443-456.

Paudel, R. B., Baral, J. B., Gautam, R. R. \& Rana, S.B. (2019). Financial Markets and Institutions. Asmita Publication.

Prasad, A., \& Ghosh, S. (2007). Competition in Indian banking: An empirical evaluation. South Asia Economic Journal, 8 (2), 256-284.

Shim, J. (2019). Loan portfolio diversification, market structure and bank stability, Journal of Banking \& Finance, 104, 103-115.

Tabak, B. M., Gomes, G. M. R., \& Da Silva Mederios, M. (2015). The impact of market power at bank level in risk taking: The Brazilian case. International Review of Financial Analysis, 40, 154-165.

Turk Ariss, R. (2010a). Competitive conditions in Islamic and conventional banking: A global perspective. Review of Financial Economics, 19, 101-108.

Turk Ariss, R. (2010b). On the implications of market power in banking: Evidence from developing countries. Journal of Banking \& Finance, 34, 765-775.

Uhde, A., \& Heimshoff, U. (2009). Consolidation in banking and financial stability in Europe: Empirical evidence. Journal of Banking \& Finance, 33, 1299-1311.

Yusiantoro, I., Soedarmono, W., \& Tarazi, A. (2019). Bank consolidation and financial stability in Indonesia. International Economics, 159, 94-104. 